\title{
Risk Prevention and Regulation Perfection of Online Loan Platforms
}

\author{
Yifan Chen $^{1}$ \\ ${ }^{1}$ School of Clothing design and engineering, Shenzhen University, Shenzhen, Guangdong 518052, China
}

\begin{abstract}
The P2P online loan platform is an intermediary between the supply and demand parties of funds to reach the loan behavior. Through the review of the development process of the online loan platform, this paper analyzes the risks contained in it, and proposes some feasible solutions for discussion and research. Finally, it puts forward insights on the future development of online loan platforms.
\end{abstract}

\section{INTRODUCTION}

In recent years, under the influence of the increasingly active private loan and the continuous progress of network technology, Internet technology has been integrated into the financial field at a faster speed, thus the Internet Finance emerges as the times require. P2P is an internet financial model, which is more consistent with the essence of internet financial disintermediation than the third-party payment, crowdfunding, $\mathrm{O} 2 \mathrm{O}$ and so on. $\mathrm{P} 2 \mathrm{P}$ is one kind of investment and financing model, which is a person-toperson or peer-to-peer information exchange. It refers to the establishment of a credit relationship between individuals directly with the assistance of an Internet platform, which can accelerate the pace of financial disintermediation and improve the utilization efficiency of idle funds. Compared with traditional bank loans, it can provide low-cost financing to individuals more conveniently. In the aspect of enterprise financing, P2P can break the existing dilemma of small and micro enterprises in financing expensive and difficult financing, and offer new ways for small and micro enterprises to finance. However, various problems have emerged during its rapid development. At the same time, there is still a lack of comprehensive relevant laws and elaborate system design in this filed to ensure the rights and interests of investors and borrowers, and a lack of sound mechanism within the industry, unable to fully self-discipline. This research probes into the risk prevention and supervision improvement of online loan platforms.

\section{DEVELOPMENT OF DOMESTIC P2P ONLINE LOAN PLATFORMS}

\subsection{Early stage (2007-2011)}

P2P online loan platform has been widely welcomed abroad and is operating in good condition, and its operation mode has quickly attracted the domestic market. The first online loan business platform in China "ppdai.com" was put into operation in 2007, which is the first time that investors from all walks of life in China know and understand the online loan platforms. Since then, P2P online loan platform in China began to boldly try business. At this time there are about 20 online loan platforms, mainly in Shanghai, Shenzhen etc., mainly including CreditEase, ppdai.com, Hongling Capital and other active platforms. By the end of 2011, the monthly turnover was about 500 million, and the number of effective investors was about 10,000 .

\subsection{Development Period (2012-2013)}

At this stage, the online loan platform has become more and more familiar to investors and financiers, and the business attracts more private capital providers to pay attention to the online loan platform more than the people in the Internet industry. Cooperation with Internet entrepreneurs such as software development companies was conducted to set up P2P online loan platform, with complementary of each other. The number of domestic online loan platforms continued to grow and the scope of influence was further expanded. Based on these conditions, the cost of setting up a platform at that time was about 200,000 , and the number of the domestic online loan platform increased rapidly from about 20 to about 200. By the end of 2012, the monthly transaction amount reached RMB 3 billion, and the effective investors were between 25,000 to 40,000 people.

\subsection{Expansion and Risk Explosion Coexistence Period (2013-2015)}

Due to the increasing influence of $\mathrm{P} 2 \mathrm{P}$ online loan, in early 2013, CCTV began to broadcast P2P online loan for many times, allowing more people in China to understand P2P. Most of the mainstream media in China also began to report online loan as a new Internet financial industry. 
Attribute to the shrinking lending policy of major banks in 2013, many enterprises or individuals who could not get loans from banks began to turn to online loan platforms for help and many people found business opportunities. At this stage, the number of online loan platforms in China had increased from about 240 to 600 or so, and the monthly transaction amount at the end of 2013 was about 11 billion, and the number of effective investors was between 90000 and 130,000 people.

\subsection{Policy Adjustment Period based on Standardized Supervision (2015 to date)}

In July 2015, the "Guidance on Promoting the Healthy Development of Internet Finance" jointly issued by ten ministries and commissions including the People's Bank of China was launched on July 18, clearly defining the division supervision responsibilities for other major Internet financial platform models such as P2P online loan, implementing supervision responsibilities, and further clarifying business supervision boundaries. So far, as the Internet financial supervision in China turns increasingly strict, the P2P industry has entered a period of policy adjustment that focuses on standardized supervision.

\section{MAJOR RISKS IN P2P ONLINE LOAN INDUSTRY}

\subsection{Lack of relevant laws and inexact supervision methods}

At present, there are very few regulations related to the supervision of P2P online loan platform in China. The existing one is just a simple management specification, and there are no relevant specifications to restrict an actual business operation. Therefore, the P2P industry does not have a systematic and standardized supervision system, and the legal problems that arise from it only remain as punishment after the fact, and the related risks are not avoided from the root cause. For example, there is no clear definition requirements on the issue of whether P2P platforms are suspected of illegal fund-raising, especially in the early stage, which cannot be identified in time. After the subsequent platform funds are broken, the crime of "illegal fund-raising" can only be convicted, but the losses caused to investors by such post-event investigation cannot be compensated, not conducive to the development of online finance in China. In addition, the existing laws in China propose not to protect loan interest rates exceeding four times, which limits the highest interest rate in the market. Besides, the lending rate of $\mathrm{P} 2 \mathrm{P}$ online loan platform has not been legally guaranteed, even though the lending rate of $\mathrm{P} 2 \mathrm{P}$ online loan platform is often higher than the legal interest rate, it has not been considered illegal.

\subsection{Defects in the information disclosure system}

The lack of transparency of P2P industry information is mainly reflected in the lack of transparency of necessary financial information and the weak disclosure of risk information. First of all, P2P industry in China is short of a financial information disclosure system. Many loan platforms will disclose their necessary financial data to the outside world, but the standards of various companies are not uniform and non-standard even if it is made public. Secondly, some P2P businesses inherently have a greater risk of default and the platform does everything possible to hide its own risks for the sake of benefits and does not disclose the risks. However, most investors lack sufficient awareness of investment risk prevention and understanding of $\mathrm{P} 2 \mathrm{P}$ lending, so $\mathrm{P} 2 \mathrm{P}$ online loan platform conceals relevant financial information, leading to that financial consumers do not have the right to know investment risks, which can easily cause huge losses.

\subsection{Lack of credit system and imperfect credit system}

At present, the $\mathrm{P} 2 \mathrm{P}$ online loan platforms on the market in China have relaxed their efforts in reviewing and regulating the credit status of both borrowers and lenders in order to promote their platforms, so that a small number of borrowers and lenders falsify personal identity information, work information and so on, so as to handle loan business. With the success of the loan, the possibility of absconding with the money is extremely high and the platform and the police may not recover the loan. At the same time, although China has established a credit investigation system for the banking industry, the P2P platform does not have the authority to directly access the credit investigation center of the central band, so the platform credit mechanism is not real enough.

\subsection{Risk of network information leakage}

The P2P platform is based on the Internet, so network information security must be avoided and guarded. The online loan platforms record the important identity information on both sides in the fund transaction which require effective protection. Actually, not all online platforms are capable of protecting the information. For the purpose of saving costs, some companies have not even set up a dedicated information management department to protect this private information. In this case, if hackers attack the personal information of these customers, they will leak the personal information of these customers. Relevant scholars also believe that some platform companies even use customer information for profit.

\section{P2P RISK PREVENTION AND MEASURES ON SUPERVISION PERFECTION}

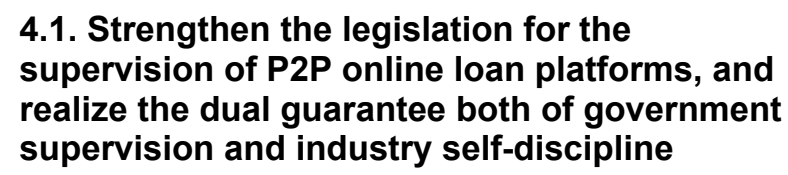
supervision of P2P online loan platforms, and realize the dual guarantee both of government supervision and industry self-discipline 
The government should strengthen the legislation for the supervision of $\mathrm{P} 2 \mathrm{P}$ online loan platforms and regulate the legality of lending platforms, and the $\mathrm{P} 2 \mathrm{P}$ industry is also required to regulate its own behavior so as to realize the dual guarantee of government supervision and P2P industry self-discipline.

Firstly, before the establishment of a P2P network lending platform, there must be three-in-one certificates materials, a "Telecommunications and Information Service Business License" issued by the Communications Administration, and it is necessary to note that the business scope of the business license records the "Internet information service". At the same time, these related departments should have corresponding supervisory responsibilities for $\mathrm{P} 2 \mathrm{P}$ online loan platform.

Secondly, strengthen the legislation for each link of P2P online loan, so that every operation has "regulations" to follow. For example, the issue of "whether it is suspected of illegal fund-raising" should be clarified "in advance", and there should be clear definition requirements to find out whether the relevant platform is illegal fund-raising in time to reduce losses.

Thirdly, the supervision system should keep pace with the times according to the changes in the overall environment, and constantly revise and formulate new systems and regulations to ensure that the $\mathrm{P} 2 \mathrm{P}$ industry is in place. The China Banking and Insurance Regulatory Commission (CBIRC), as the supervisory authority in China, not only needs to strengthen the promulgation of relevant laws and regulations, and the formulation of detailed rules, but also promulgate laws, regulations and other documents related to risk monitoring and early warning in P2P industry. Additionally, CBIRC should strengthen communication and cooperation with various regulatory authorities, share information, put forward constructive suggestions to improve the system continuously, and promote the long-term, harmonious and orderly development of P2P industry.

\subsection{Construct an information disclosure system for P2P online loan platform and establish a mandatory information disclosure system}

Whether a good information disclosure system can be constructed is the key to the development of P2P online loan market. When constructing an information disclosure system for $\mathrm{P} 2 \mathrm{P}$ online loan platforms in China, mandatory information disclosure should be implemented to protect investors. As for contents, methods and standards of mandatory information disclosure, mandatory information disclosure is a statutory obligation, and the P2P online loan platform will bear corresponding legal liabilities upon breaching. In terms of content of mandatory information disclosure, when designing the mandatory information disclosure content of P2P online loan platforms in China, we must proceed from the perspective of investor protection, focusing on the following content:

(1). Borrower information. Due to the fact that online loan platforms use the Internet to facilitate the lending relationship between strangers, investors need to clearly guide the borrower's information. The information that the borrower must disclose is mainly the borrower's credit status, the amount of the loan and the purpose.

(2). Transaction risk. Since most of the investors participating in the online loan business are people who lack investment knowledge mostly, so focusing on protecting investors means it is necessary for the platform to fully implement its risk notification responsibilities when issuing investment projects, so that investors can understand the relationship between the risks and returns of this investment clearly to assure investor's right of knowledge and option (include loan amount, deadline, interest rate, service rate, repayment way etc.).

(3). The operation information of $\mathrm{P} 2 \mathrm{P}$ online loan platform. As a trading platform for investment business, good operation conditions are also an essential condition to ensure the normal progress of investment business. Therefore, the operation information of $\mathrm{P} 2 \mathrm{P}$ online loan platform must also be included in the scope of mandatory disclosure

Specifically, the following information must be disclosed in a forced manner: 1 . The corporate operation status of the P2P online loan platform; 2. The operation model of $\mathrm{P} 2 \mathrm{P}$ online loan platform, including the credit evaluation methods it adopts, the matching mechanism between investors and borrowers, the fund management system given by investors to the platform, and specific information on third-party and third-party guarantees; 3 . The business data of P2P online loan platform, including transaction amount, cumulative number of users, average single loan amount, investor income, non-performing loan indicators and so on. The operation information of the above-mentioned $\mathrm{P} 2 \mathrm{P}$ online loan platform has a great influence on the investors' choice, so it must be compulsorily disclosed to achieve the purpose of ensuring investment security.

\subsection{Online Loan Platform Incorporated into Credit Reporting System}

On September 2, 2019, the Leading Group for the Special Rectification of Internet Financial Risks and the Leading Group for the Special Rectification of Online loan Risks jointly issued the "Notice on Strengthening the Construction of the Credit Reporting System in the P2P Online loan Field" (hereinafter referred to as the "Notice"), which has aroused widespread concern in the industry. The issuance of the "Notice" will effectively prevent malicious evasion of debts, non-repayment of overdue and other behaviors, and the Internet financial field may usher in a new spring. As the "Notice" states that P2P online loan institutions, whether in operation or withdrawn from operation, will be fully integrated into the Credit Reporting System. Uncredited people in the field of online loan may be treated disciplinary measures such as raising loan interest rates and restricting loan provision. The "Notice" proposes to support operating P2P online loan institutions to access financial credit information basic database operating institutions, Baihang Credit and other credit reporting agencies. Credit reporting agencies need to collect, collate, preserve, process and provide credit information in accordance with laws and regulations to 
protect the legitimate rights and interests of information subjects. The full access of P2P online loan institutions to the Credit Reporting System is one of the effective supporting measures for the industry to safely resolve risks. Furthermore, all localities are encouraged to establish an inner-departmental joint disciplinary mechanism in accordance with laws to increase social disciplinary action against uncredited behavior. Mutiplatforms borrowing and malicious evasion of debts have been prominent problems in the development of P2P industry. The promulgation of the "Notice" will increase the cost for borrowers who repudiate a debt, which may reduce the bad debt rate of $\mathrm{P} 2 \mathrm{P}$ enterprises. The "Notice" also emphasizes that if the interest rate of $\mathrm{P} 2 \mathrm{P}$ institutions exceeds the lending interest rate supported by the People's Court in the Provisions of the Supreme People's Court on Several Issues Concerning the Application of Laws in the Trial of Private Lending Cases, the information subject shall have the right to raise objections to credit reporting institutions or P2P online loan institutions and request corrections in accordance with the "Regulations on the Administration of Credit Reporting Industry", meaning further transparency of information. P2P access to the Credit Reporting System is not only a requirement for investors' lenders, but also for P2P institutions themselves. The transparency of interest rates is conducive to reducing trick loans.

\subsection{Strict Review Information to Promote the Improvement of Prevention and Control Capabilities}

P2P platform is a kind of information intermediary agency, which should strengthen the management of lender and borrower information, so that the security and legitimacy of collecting, processing and use of lender and borrower information can be effectively guaranteed. Taking Information supervision as the focus of P2P supervision, information should be fully disclosed to accelerate the establishment of anti-money laundering mechanisms and real-name systems on the $\mathrm{P} 2 \mathrm{P}$ platform. Internet lending information intermediaries, other kinds of outsourcing service agencies, etc. shall strictly keep confidential the information of the lender and borrower collected in the course of conducting business, strictly avoid the use of the information of the lender and the borrower in addition to the services provided without the consent of lender and the borrower. At the same time, the P2P platform should disclose real-time information on the operation and management of loan projects matched by the institution in a prominent position on the official website, such as the number of transactions, amount, loan balance, customer complaints and so on, so as to disclose and transparent information.

In short as an Internet financial business model, P2P online loan is featured by the characteristics of fast, convenient and flexible, so it has developed rapidly in recent years. However, under the influence of factors such as operational prescriptions and legislation lag and so on, all kinds of risks such as loss of connection and running off of P2P online loan platforms have appeared continuously, causing serious interference to normal financial order and social stability. To enable health development of $\mathrm{P} 2 \mathrm{P}$ online loan platform, relevant departments should thoroughly analyze the current P2P online loan platform's operating mode and possible risks, and then put forward policy recommendations.

\section{REFERENCES}

[1] Wang Lamei. View on the Construction of the Information Disclosure System of P2P Online loan Platform in China [J], South China Finance, 2015 (07):76-79+ 21 .

[2] Zhu Wei. Study on the Perfection of the Legal Supervision System of P2P Online loan Platform [J], China Journal of Commerce, 2019 (05):231-232.

[3] Zhang Lu. Analysis of P2P Online loan Risk Supervision and Development Issues in China [J], Northern Economy and Trade, 2019 (05):112-113. 